Article

\title{
Energiewende's Lone Warriors: A Hyperlink Network Analysis of the German Energy Transition Discourse
}

\author{
Jonas Kaiser ${ }^{1, *}$, Markus Rhomberg ${ }^{1}$, Axel Maireder ${ }^{2}$, Stephan Schlögl ${ }^{3}$ \\ ${ }^{1}$ Faculty of Political and Social Sciences, Zeppelin University Friedrichshafen, 88045 Friedrichshafen, Germany; \\ E-Mails: j.kaiser@zeppelin-university.net (J.K.), markus.rhomberg@zu.de (M.R.) \\ ${ }^{2}$ GfK Austria, 1030 Vienna, Austria; E-Mail: axel.maireder@gfk.com \\ ${ }^{3}$ Institute of International Development, University of Vienna, 1010 Vienna, Austria; \\ E-Mail: stephan.schloegl@univie.ac.at \\ * Corresponding author
}

Submitted: 11 January 2016 | Accepted: 25 March 2016 | Published: 11 August 2016

\begin{abstract}
This paper explores the integration of different social fields within the German Energy Transition (Energiewende) discourse in the election year 2013 by analysing the hyperlink structures online. Energiewende describes the fundamental transition from non-renewable energy to sustainable sources. This goal is both ambitious and controversial. Numerous stakeholders try to make their voices and interests heard and as such politics has to both disseminate and collect information in order to include all relevant groups from different social fields in the political process. This discourse is also visible online. By analysing the hyperlink structures we are able to see the attention distribution of different actor groups in the network. This study shows that most actors tend to link within their own social field and do not aim for a more integrated public sphere. Especially political actors appear to be lone warriors who neither look left or right and mostly link within their own party and ignore other actors. Whereas social field as the media or public administration are relevant within the network we find that scientific actors are ignored by all fields, except for their own.
\end{abstract}

\section{Keywords}

energy transition; Energiewende; environment; hyperlink publics; network analysis; online communication

\section{Issue}

This article is part of the issue "Political Agency in the Digital Age: Media, Participation and Democracy", edited by Anne Kaun (Södertörn University, Sweden), Maria Kyriakidou (University of East Anglia, UK) and Julie Uldam (Roskilde University, Denmark).

(C) 2016 by the authors; licensee Cogitatio (Lisbon, Portugal). This article is licensed under a Creative Commons Attribution 4.0 International License (CC BY).

\section{Introduction}

On March 11, 2011 a tsunami led to a meltdown at the nuclear power plant in Fukushima with disastrous consequences for the Japanese population. Besides the sympathies for the direct victims of this catastrophe, Fukushima evoked a new discussion on energy policy in Germany. As a reaction the Federal Government enacted a so-called "Atom-Moratorium"-a pause that soon led to a withdrawal from the previously decided lifetime extension of nuclear reactors. Likewise, Chancellor Merkel appointed an ethics committee to find a social consensus regarding the nuclear phase-out and to compile proposals for the transition to renewable energies. Due to these events the German term "Energiewende" ("Energy Transition") became once again the heart of the public and political debate in Germany. The term describes the fundamental transition from non-sustainable energy sources like nuclear or coal to sustainable sources like solar power, biomass or wind-a transition that has wide-reaching consequences for every part of society. Not only has the Energiewende social consequences, its success is largely depending on the integration of 
vital parts of the society in the adaptation process. As many other great transformation issues like climate change, sustainable living or social policies, the implementation of the Energiewende is very complex and "wicked" (Rittel \& Webber, 1973). By wickedness problems are described that are difficult to solve because of incomplete, contradictory and changing requirements and the need to integrate a large number of stakeholders in the process (Rhomberg \& Stehr, 2012).

Public debates and the integration of different stakeholders and publics can be best understood through the lens of public sphere theory (e.g. Kleinenvon Königslöw, 2010). The integration of actors (especially from civil society) from different social fields within the public sphere-often times understood as the mass media-, however, was mostly poor (e.g. Ferree, Gamson, Gerhards, \& Rucht, 2002). The Internet in this sense was supposed to foster the integration of different publics and create a better, i.e. more open and inclusive public sphere (e.g. Benkler, 2006). One concept that attempts to account for the changes the Internet had on public communication, participation and society in general is the concept of the networked public sphere (Benkler, 2006; Neuberger, 2009). Indeed, a growing body of research indicates that Internet communication has increased the interweaving of publics and intersections between the different spaces that make up the public sphere (Benkler, 2006; Nahon \& Hemsley 2013; Neuberger, 2009). Kleinenvon Königslöw (2010) in this sense suggests that one main criterion for the integration of the public sphere is the degree of connection between the different publics. Integration is either achieved on a basal level through observation (i.e. all publics observe each other) or on a more advanced level through the integration of actors from other publics in one's own public (pp. 58-62). The integration of different social fields is especially important for a wicked issue like Energiewende, since stakeholders from different social fields need to be integrated to implement it. As actors from one social field tend to stay within their own field (Giddens, 1984), we extend Kleinen-von Königslöw's (2010) integration approach to social fields. Since the Internet offers actors from less influential fields to form alliances, reach other social fields and influence public opinion (Benkler, Roberts, Faris, Solow-Niederman, \& Etling, 2015) we will focus in this paper on the question of how well the political field is able to integrate other social fields within the Energiewende discourse. Hyperlink analysis is a welltested digital method, which allows us to analyse this question. This paper, then, adds to this special issue by critically assessing the potential of digital media for political agency in the case of the German Energiewende.

Therefore, our analysis focuses on the hyperlink structures between different actors and on the attention that these actors pay to each other. Usually these processes of attention attribution between actors are not visible to scholars but a growing body of literature has shown that it is to some extent visible online (e.g. Adamic \& Glance, 2005; Benkler et al., 2015). We assume that public spheres are constituted by condensed networks of communication and understand the public and segmented publics respectively as forms of communicative aggregation (Habermas, 2006; Latzer \& Saurwein, 2006). Such agglomerations evolve especially when social actors communicate about shared problems and interests, and thereby refer to each other. Referring to each other in our perspective indicates paying attention and thereby assigning relevance to certain social actors. In this paper, we measure the attribution of relevance on the base of Internet communication's hyperlink structures. Hyperlinks serve as indicators of relevance on the Web that construct structural vectors, which establish association between websites that allow users to navigate between them.

Since this article focuses on the integration of different social fields we first have to ask: how is the Energiewende hyperlink discourse structured with regard to actors and social fields? We will then take a closer look at the role of the political field and how well it is able to integrate different fields in the political communication processes of the policy field Energiewende, and whether the political actors are actively distributing and collecting information in order to include as many actors in the political process as possible.

Surprisingly, there are only a few studies on the field of the Energiewende (e.g. Kemfert \& Horne, 2013; Sohre, 2012). Studies with a focus on political communication and the communicative interactions and the public debate between these fields are missing completely. We therefore aim to close this gap by examining the online public debate on the Energiewende in order to systematically identify the active stakeholders that deal with this problem and how they interact with each other. In this context it is both important to identify the specific involved actors but also, for a larger pattern, the social fields.

By empirically analysing the hyperlink-structures of the Energiewende debate, this paper also seeks to give insights on how far communication in the Internet can contribute to the integration of social segmented publics and therefore promote democracy. In order to answer our questions, we first explain the case of the Energiewende and highlight the most relevant actors (based on indegree, i.e. the amount of links one actor received from others). We then explain the significance of hyperlink publics within this context, then posit the research questions and clarify our methodology and finally describe our results and what these entails for this study as well as for future research. 


\section{Framework and Research Question}

\subsection{The German Energiewende}

Energiewende is about to become an international synonym for a major energy system transformation. It was originally coined by the German Institute for Applied Ecology ("Öko-Institut Wuppertal") in 1980. It found its way into the political debate no later than in 2002, when the Social Democrats and the Greens formed a coalition government. The term lost its political grip in the following years, and required a window of opportunity in 2011 provided by the Fukushima disaster to bring the issue back on the top of the public and political agenda. The German government intends to change its overall energy system by shutting down all nuclear power plants by 2022 and reducing greenhouse gas emissions by at least $80 \%$ by 2050 (BMWi \& BMU, 2012) ${ }^{1}$. With the Energiewende Germany also aims to increase the share of renewable energy for electricity production to $80 \%$ by 2050 (cf. Kemfert \& Horne, 2013, p. 1). This transition does not only concern the German energy sector, for which the Energiewende is a major economical challenge but also affects the German society as a whole, since the resulting issues touch upon political, economic, social, scientific, technological and ecological aspects. As The Economist (2012) puts it: "The Energiewende raises costs, unsettles supply and provokes resistance at grass-roots level." Hence it is not really astonishing that this complex issue affects many interests of companies, citizens, politicians as well as NGOs and that it became a major issue in election campaigns in Germany (Althaus, 2012). The first election after Fukushima, for example, resulted in the first coalition government with a Green majority in March 2011 in the federal state of BadenWürttemberg. The election of the German Bundestag on September 22, 2013 was the first nationwide vote after the introduction of the Energiewende.

The complexity of the issue, the need to integrate a broad range of stakeholders, the uncertainties concerning technological innovations, the relationship between renewable energies and fossil fuels, the debates on a Post-Kyoto climate regime and the interwovenness of the German energy sector in the European market lead to the assumption that the Energiewende is a good example for a "wicked" problem (Rittel \& Webber, 1973). What makes a problem wicked is on the hand the impossibility of giving it a definitive formulation: the information needed to understand the

\footnotetext{
${ }^{1}$ German Federal Ministry for Economic Affairs and Technology (BMWi-Bundesministerium für Wirtschaft und Technologie) and German Federal Ministry for the Environment, Nature Conservation, Building and Nuclear Safety (BMUBundesministerium für Umwelt, Naturschutz und Reaktorsicherheit).
}

problem depends upon one's idea for solving it. "In fact, it's the social complexity of wicked problems as much as their technical difficulties that make them tough to manage" (Camillus, 2008, p. 98). Because wicked problems are embedded in social contexts, embrace a broad range of stakeholders from different social fields with their specific and often contradicting interests, and solving wicked problems depends on integrating the needs and stakes of actors from different social fields, decision-making on these issues is especially challenged by a vital public debate and major efforts of these groups to strategically gain influence on decision-making with public pressure. The logic of the Internet as potentially non-hierarchical and nonlinear communication infrastructure not only calls for new modes of political discourse, it potentially allows actors without formal access to decision-making processes and without high social and financial status to gain more influence in the debate.

For the framework of this paper it is important to highlight that the implementation of the Energiewende does not only depend on political actors on different spatial levels, but can also be influenced by different other interest groups from the economic sector, science, NGOs and civil society via strategic public pressure. Although there are various policy-analyses on interest and pressure groups in the policy-making process of the Energiewende, these analyses especially highlight already established and accredited actors. However, these studies serve as a starting point to gain insights in the field. They subsume actors into two different streams: the "conventional energy coalition", which aims to maintain the status quo of the energy system, and the "sustainable energy coalition", which "argues that the current costs of the Energiewende have to be seen as long-term investments that will pay off in the light of rising energy prices and decreasing costs for renewable energy equipment" (Kemfert \& Horne, 2013, pp. 6. 7; see also Gawel, Strunz, \& Lehmann, 2012; Kemfert, 2013; Sohre, 2012). The conventional energy coalition comprises political actors like the BMWi, the CDU/CSU, FDP, private companies, energy producers, the transmission system operators, the energy intensive industries as well as their interest groups. The sustainable energy coalition is supported by renewable energy companies and their associations, the renewable energy manufacturers, various environmental groups and NGOs as well as by the BMU, the Green party, large parts of the Social Democratic Party and research institutes in the fields of renewable energy, energy efficiency, storage and grid technology (cf. Deutsch, Krampe, Peter, \& Rosser, 2014; Graichen, 2014; Graichen \& Redl, 2014).

Although we conclude that the debate is shaped by a diversity of actors and interests, we nevertheless can systematize different groups: the political field (parties and executive branch), economic interests, scientific 
experts, NGOs and environmental groups as well as civil society actors. Due to its decision making-competence, the political field is located in the centre of the debate. The other groups of actors are trying to influence political actors by setting the agenda for energy policy with multiple strategies: These strategies can be operated in the public or non-public. Since public acts like direct communication or referring to each other on a website is one way to publically show allegiance or alliances (e.g. scientific networks) and be transparent and accountable to the public we are looking at the hyperlink connections between websites. These offer scholars new ways of analysis and interpretation and we will thus take a closer look at hyperlink publics.

\subsection{Hyperlink-Publics}

Our perspective on this debate is based on structural theories of the public sphere. We understand the public sphere as complex network of multifaceted spheres of communication. These spheres can be structured alongside thematic threads ("horizontal categorization", Wessler, 2002), common interests ("publics", Gruning \& Hunt, 1984), shared forms and types of communication, different authorities of actors as well as groups of actors on different spatial levels. Actors communicate within and across these spheres on collective issues like Energiewende, connecting different publics and linking topics and opinions.

In contrast to a public sphere primarily structured by mass media, the Internet-based networked public sphere (Benkler, 2006) is characterized by an inclusion of a wide range of actors into the public discourse and manifold options for connection between different spaces and levels of the public sphere. This may lead to a more integrated public sphere. However, the Internet may also lead to a more fragmented public sphere which consists of several loosely connected publics that do not observe each other and thus can be considered a danger for democracy (Sunstein, 2001). The major form of connective structure online is the hyperlink, a vector that links documents, establishes association between digital objects, and allows users to navigate between sites and services. Despite the fact that hyperlinks may have different meanings (Harrison, 2002), all of them reallocate attention and transfer relevance across social contexts. Hyperlinks in this sense can be understood as a proxy for integration practices with regards to observation of other publics and/or integration of actors from other social fields within one's own field (Kleinen-von Königslöw, 2010).

Researchers have been studying the networks emerging from the interlinkage of websites for almost two decades, often regarding websites as actors and interpreting the hyperlink patterns between them as social association (Adamic \& Glance, 2005; Park, 2003) or paths for the flow of information (Chang, Himelboim,
\& Dong, 2009). Hyperlinks between documents within a specific public discourse-defined as the set of information (fact, interpretation and opinion) pertaining to an identifiable theme-are indicating connections between different statements and thus different parts of the overall debate. They also suggest associations between the actors that published the respective documents. Furthermore, documents (and actors) linked to by large numbers of actors can be considered particularly important to the discourse as a whole, because they have been marked relevant by participants from different fields of society.

In the context of the Energiewende discourse, hyperlinks may show how different groups of actorspolitical parties, administrative institutions, for-profit companies, non-profit organizations or citizens' initiatives-assign relevance and express association to others within a specific topic. It is a particular form of expression, because it is publicly observable. Hence, hyperlinks are indicators of association that actors explicitly state and the hyperlink network on the Energiewende discourse is the aggregation of those explicit expressions. At the same time, the discourse hyperlink network is not only representing association, but it is the structure Internet users navigate in when they seek information on Energiewende. For those reasons, we regard the structural analyses of hyperlinked-based actor networks a potentially fruitful approach to the study of a complex discourse on a wicked and farreaching topic like Energiewende.

\subsection{Research Questions}

This paper seeks to investigate the integration of different social fields in the Energiewende hyperlink discourse and especially if and how political actors contribute to said integration. Since we are mainly interested in understanding the network's structure and politics' role in it we opt for three explorative research questions. Taking the debate on the Energiewende on the one hand and our understanding of the public sphere on the other hand, our first question focuses on the social fields' productivity, in terms of published documents about the Energiewende:

RQ1. Which social fields are the most "productive" ones?

Since the Energiewende discourse is closely connected and in the end being managed and decided by political actors, we are especially interested in the way political actors are linked to (RQ2) and link themselves (RQ3) since it can be assumed that political actors might want to build a broad coalition with different actors to tackle this wicked issue. We thus ask:

RQ2. Which actors link to the political field? And 
which political actors are the most prominent link targets?

RQ3. Which social fields and which specific actors are the most linked to by the political field?

With these questions we want to focus on political actors and address how they see themselves but also how they are seen by others in the Energiewende discourse.

\section{Research Design}

Most hyperlink network studies start with predefined lists of websites and then manually or (semilautomatically retrieve links from those websites. Many studies retrieve all links from a certain website to other sites, while others include only a certain type of link-in the case of blogs, the 'blogroll' for example. Because many studies aim to objectify the network of a previously defined set of actors, hyperlinks to websites not included in the original selection are ignored (cf. Adamic \& Glance, 2005; Chang et al., 2009; Hsu \& Park, 2012; Schumate, 2012).

Our approach, however, is different: First, the focus on specific websites can be seen as a limit to a study's explanatory power since it restricts an otherwise fluid and emergent linked "discourse"; thus the actors that collectively create it cannot be identified beforehand and bundled into a fixed set. Second, reconstructing the interrelationships of these actors as a whole (like many traditional hyperlink network studies) would not necessarily reveal anything about a particular discourse, as actors tend to participate in multiple discourses simultaneously. Hence, we do not start with a fixed set of actors and grasp all hyperlinks on the sites, but use keyword-based web data retrieval and scraping techniques (Stieglitz \& Dang-Xuan, 2012) and combine those with hyperlink network analyses in an effort to determine the structure of the Energiewende discourse through the network of hyperlinks that connect messages containing these keywords.

The findings we present in this paper do not include content from social media platforms like Facebook or Twitter since these are often times not public, introduce new vectors like shares or retweets that cannot be equated with hyperlinks and would skew the network analysis as every profile page can be considered to be a unique actor. Against this background hyperlinks are a well-tested vector for the identification of key actors within a public and how these are connected with each other (see Section 2.2).

\subsection{Data Retrieval \& Scraping}

We used Google's search engine to grasp documents that included the term 'Energiewende' within a period of 30 weeks, starting in March 2013 when the first party conventions were held, and ending in October 2013 one month after the election of the German Bundestag on September 22. We conducted automated search requests on a daily basis and saved all entries that had been published or at least updated within the last 24 hours using the 'time range' option. Next, we deleted all duplicates based on the documents' URL, resulting in a total of 70204 unique documents from 7911 unique domains. Document in this context refers to a unique webpage accessible via Unified Resource Locator (URL) on a website (e.g. a news article is the document whereas its parent site on which the article is hosted is the domain).

We then automatically accessed each of the collected URLs and retrieved all the hyperlinks they contained. We identified a total of more than 6 million hyperlinks of which the majority led to other documents on the same domain. In order to create a network of hyperlinks between documents addressing the issue of Energiewende, we just kept the references that pointed to URLs we had previously identified. We will furthermore refer to the resulting network as the 'document-network'. Next, we merged all documents by their respective domains (e.g. spd.de, spiegel.de), resulting in a 'domain-network' as a network of actors that individually or collectively took part in the discourse through a specific medium. In order to hold true for this assumption we counted subdomains of blogging platforms like 'michael.wordpress.org' or 'michael.blogger.com' as domains, although technically they are not. In order to being able to properly work with the network and code the domains we then reduced the network to the largest weakly connected component that contained 2086 nodes and 4803 edges. This 'domain network' was the main object of the further analyses.

\subsection{Coding}

Because we were interested in the patterns of association between different groups of actors, we manually assigned each domain to one of 8 categories representing social fields. Those fields are Public Administration (governmental and parastatal institutions), Politics (politicians, political parties), Economy (for-profit companies), Special Interest Groups (SIG; organizations with specific social aims), Media (both websites of traditional mass media and alternative media), Science (universities or private research institutes), Civil Society (non-affiliated individuals and citizens' groups) and others. Two graduate students coded all domains based on the appearance of the website and information of the website's imprint. The pre-coding intercoder reliability test showed a Krippendorff's alpha of 0.76.

Based on the coding, we grouped nodes and edges accordingly and calculated network metrics in an effort 
to describe the interrelations between the fields and actors and thus answer our research questions properly.

\section{Results}

When looking at the Energiewende hyperlink network a few things are interesting to note (see Figure 1 ). We computed a community detection algorithm on the network (Blondel, Guillaume, Lambiotte, \& Lefebvre, 2008), which identified several communities (54) and a rather high (0.6) modularity for the resulting partition. This indicates that the communities are only loosely connected to each other and that the Energiewende public is generally weakly integrated. We can also see the relevance of mass media actors for the Energiewende network. This importance is naturally closely connected to the topic's relevance for Germany, which forces the media to cover it in depth. In the next sections we will focus on our research questions in order to identify the most relevant fields and take a closer look at the relevance of political actors and their linking habits.

\subsection{Productivity of Social Fields in the Energiewende Network}

While comparing social groups and sub groups by productivity certainly has its purpose, it also neglects the question of relevance. Since the Internet enables anyone to potentially blog about Energiewende on a daily basis this, of course, does not make the blog inherently relevant for others. There are further factors like status (of- ten times transferred from the "offline world"; cf. Gonzalez-Bailon, 2009) or expertise that may make an actor more important within a network even though the actor is not necessarily very productive. A person's weblog, which gets updated twice a day, will still, most likely, be less relevant to others than an article by an official government body. This assumption is reflected by our results: Whereas we understand productivity by documents published on Energiewende we assume one actor's relevance as the amount of times $\mathrm{s} /$ he was linked to by others (Indegree) since links are-as stated above-a way of attributing relevance.

As Table 1 shows Media is-not surprisingly-the most productive field within our network with over 36,618 documents regarding Energiewende and as such fulfilling its function of reporting about the process, its (dis)advantages and other relevant news. Interestingly, Media is also one of the most relevant social fields with an average indegree of 2.76. As can be seen in Table 2 a prime example would be the conservative quality newspaper Die Welt's online outlet (welt.de; Mueller, Ligensa, \& Gendolla, 2009) which has published over 859 documents and has also an indegree of 86 , thus making it the most productive as well as relevant media outlet in the Energiewende network. It is also interesting to note that most of the country's quality newspapers (e.g., faz.net, spiegel.de, handelsblatt.de, heise.de, sueddeutsche.de; Mueller et al., 2009) are both productive and relevant within the network and thus demonstrating the media's importance and relevance in such a complex and abstract issue.

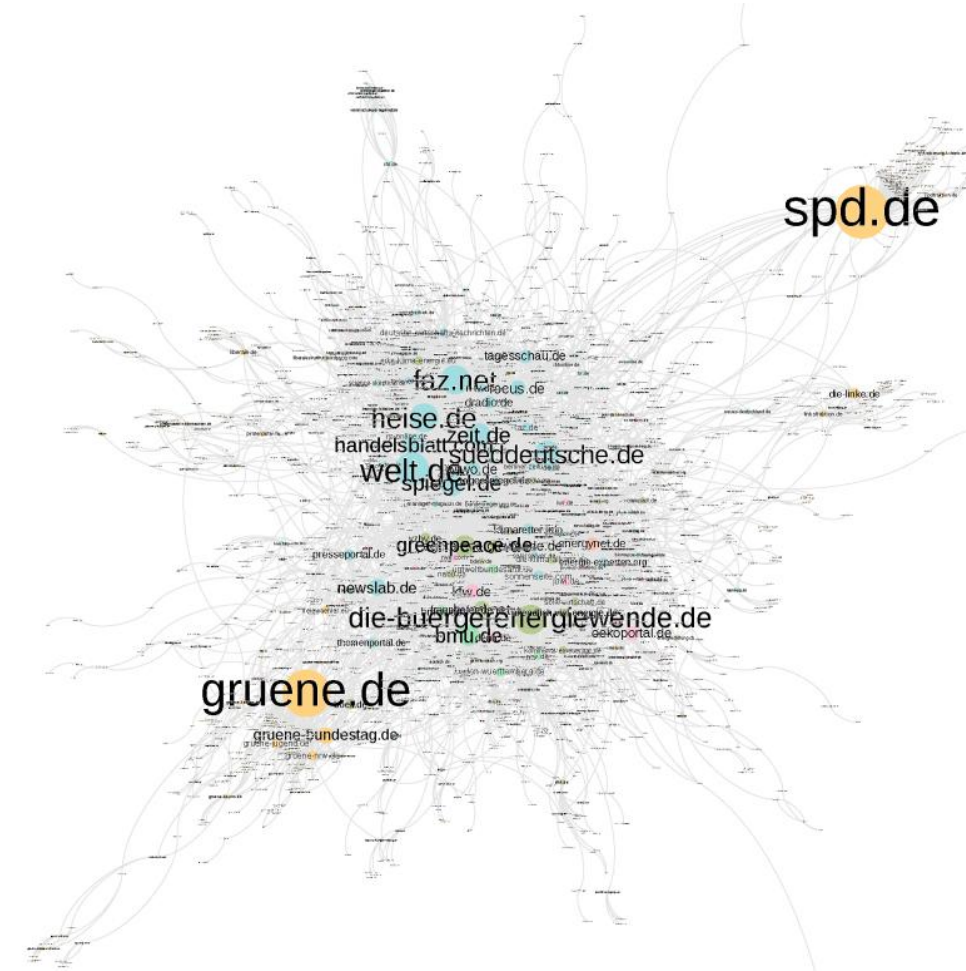

Figure 1. Hyperlink-Network of all domains (node size by indegree, node colour by coded societal field, layout algorithm: ForceAtlas2). 
Table 1. Links from social field to social field.

\begin{tabular}{lllllllll}
\hline & SIG & Media & Politics & $\begin{array}{l}\text { Public } \\
\text { Administration }\end{array}$ & Economy & Science & $\begin{array}{l}\text { Civil } \\
\text { Society }\end{array}$ & $\begin{array}{l}\text { Other } \\
\text { SIG }\end{array}$ \\
Media & 181 & 149 & 11 & 32 & 39 & 12 & 24 & 3 \\
Politics & 372 & 1098 & 96 & 137 & 222 & 76 & 60 & 17 \\
Other & 45 & 60 & 572 & 25 & 3 & 1 & 10 & 3 \\
Public Administration & 26 & 158 & 10 & 11 & 16 & 9 & 10 & 17 \\
Economy & 10 & 9 & 4 & 32 & 4 & 5 & 0 & 0 \\
Science & 85 & 262 & 15 & 48 & 133 & 16 & 25 & 1 \\
Civil Society & 18 & 22 & 1 & 18 & 13 & 39 & 2 & 0 \\
\hline Total & 109 & 263 & 21 & 13 & 41 & 6 & 53 & 10 \\
\hline
\end{tabular}

Table 2. Actor productivity (by documents published) and indegree.

\begin{tabular}{lll}
\hline Actor & Documents & Indegree \\
\hline spd.de & 15 & 111 \\
gruene.de & 60 & 108 \\
welt.de & 859 & 86 \\
die-buergerenergiewende.de & 121 & 77 \\
faz.net & 1112 & 76 \\
heise.de & 400 & 75 \\
sueddeutsche.de & 280 & 70 \\
spiegel.de & 901 & 61 \\
zeit.de & 234 & 61 \\
handelsblatt.com & 492 & 59 \\
\hline
\end{tabular}

Table 3. Social fields' indegree.

\begin{tabular}{llll}
\hline Social field & Domains & Documents & Av. Indegree \\
\hline SIG & 243 & 1927 & 3.50 \\
Media & 735 & 36618 & 2.76 \\
Politics & 417 & 1291 & 1.76 \\
Public Administration & 64 & 815 & 4.94 \\
Economy & 261 & 3049 & 1.81 \\
Science & 74 & 545 & 2.22 \\
Civil Society & 175 & 883 & 1.06 \\
Other & 117 & 929 & 0.4 \\
\hline
\end{tabular}

An indicator that suggests that productivity does not necessarily imply relevance however are the fields of Public Administration and, to some extent, SIG. Both are not extremely productive but obviously are very relevant in the network. This holds especially true for Public Administration which is naturally an authority on the subject of Energiewende but which only published 815 documents in our investigation period (44 less than welt.de) and still has an average indegree of 4.94 and thus the highest of all fields. As can be seen in Table 2 both administrative institutions, the BMU (bmu.de) as well as the BMWi (bmwi.de), have a high indegree without being very productive. Another not so lively group of actors, which is highly relevant within the network, is SIG with 1927 published documents from 243 domains and an average indegree of 3.49. Its importance can be explained by the Energiewende's wide-reaching consequences for all parts of society and the interest groups' attempt to channel those. Espe- cially foundations like Agora Energiewende (which specifically deals with the Energiewende and its associated consequences and issues) or environmental NGOs like Die Bürgerenergiewende, Greenpeace or BUND took the opportunity and established themselves as relevant actors within the discourse; something which can also be seen in the network (Table 2).

It is also rather interesting to see the two German political parties SPD (spd.de, indegree 113) and The Greens (gruene.de, indegree 109) having the highest indegree in the network even though they haven't been very productive. This is even more striking since the political field has a lesser indegree than Science and is on the same level as Economy; both fields have published less documents together than the political field did (see Table 3). When looking at Table 2 it is, of course, evident that there a few relevant domains within the political group but the field consists of neither productive nor relevant actors. 
We were able to show that Media was the most productive field in our network. However, the fields of Public Administration and SIG were both more relevant within the network.

\subsection{Links to Political Actors}

Second, we investigate which social groups, and specifically which actors, link to the political field and which political actors are the most prominent link targets since this might indicate which fields or actors may try to integrate politics within the Energiewende public.

Keeping the previous results in mind it is especially fruitful to focus on the question, who deems the political parties relevant. As Table 3 shows, the field that links most to political actors is Politics itself. Over $79 \%$ $(n=572)$ of incoming links to political actors came from within the field itself. And most of the times these links even stayed within the own party network. In fact, there are only 3 cross-party references: two links from SPD to the Greens and one from a Green politician to the official Green party's Austrian website. Except for those no political actor linked to another political group, who was not within his/her party. The parties' local and regional subsidiaries and the respective parties' hierarchies can explain this number and especially the main party website's relevance within the network. Most of the links to the Greens, for example, stem from the Greens themselves and this is also true for the other parties. This self-referentiality is especially noteworthy with the German Social Democrats where almost $90 \%(n=165)$ of incoming links stem from its own party network.

The other field that relatively often ( $13 \%$ of politics' incoming links) links to political actors is the Media. And even though this number may seem high in comparison to other fields it demonstrates how seldom $(n=96)$ actors actually link to the websites of political parties. Adding from Table 1 it rather can be detected that if someone choses to link to political content, the official sites from the Federal Government (Public Administration) are chosen. Nevertheless, there are actors that explicitly refer to political actors. The most productive actor that regularly links to the political field is the conservative weblog Freiewelt.net, which sees the Energiewende rather critical. It is, however, also worth mentioning that the party-affiliated foundations from the Green party and the liberal party often times refer to their respective party website and thus make their affiliation obvious.

Within the political field the most prominent single actor targets are-as shown above-the main homepages of SPD (indegree 111) as well as Greens (indegree 108) and then by a wide margin the Green faction in the German parliament (indegree 43), followed by the official website of the left party Die Linke (indegree 28). It is also very telling that of all 417 political actors that broach the issue of Energiewende only 148 are linked to at least once, with the main party websites being the most linked to and thus showing the party hierarchies and allocation of power.

The results show that the field of Politics is very self-referential and almost exclusively links within one party's own network with the main website as most important link target.

\subsection{Links from Political Actors and the Network's Interconnectedness}

Third, we examine which social fields and which specific actors are the most linked to by the political field. While we already asserted, that the political field is mostly occupied with itself, we want to understand the extent to which some political actors are trying to integrate other actors.

We already covered the phenomenon that most of the political links refer to actors within the political field. It has to be noted though that there are some remarkable results within Politics' linking habit. One is the lack of links to Science. Only the small ecological party ÖDP linked once to the Umweltinstitut and thus to a scientific actor. All other parties refrained from doing so. Especially since Energiewende is such a complex issue which touches upon questions of energy security, renewable energy efficiency, energy markets or energy alternatives it is surprising that politics do not seem to regard scientific actors as relevant-at least when it comes to referencing them.

When actors from the political field do link to another field they link to websites from Public Administration (7.9\%). This can be explained with political parties referring to public authorities to validate their demands or, in some cases, because political actors are also part of the Public Administration. Within this context it is interesting to note that only $3 \%$ of outgoing links refer to actors from the media. This may indeed show politics' unwillingness to let the media shape their agenda. The second most linked field by political actors is Civil Society (5.4\%). The third most linked to is SIG (5.3\%). Especially actors from the civil society sector like boell.de were prominent link targets for political actors. These websites were linked to mainly by the Greens. $^{2}$ This does not only show how important Special Interest Organizations are in the Energiewende discourse but also allows for a picture of whom the political parties feel "close" to. Since hyperlinks are consciously added and thus a reference of importance, the connection between a party and a lobby organization, for example, makes an otherwise rather implicit connection visible.

\footnotetext{
${ }^{2}$ It has to be noted that the Heinrich Boell Stiftung is the Green party's foundation and thus the connection between these two actors is not very surprising.
} 
As the political actors did not fulfil the central position we assumed they would, we further investigated whether the self-referentiality is prevalent in all fields we found or whether there are other, more interconnected fields. As Table 3 shows there are four more fields where most of the links stay within the field (SIG, Media, Public Administration and Science). And even though these fields link up to $52 \%$ to their own field's actors they don't come close to Politics (79.55\%). Two fields, however, linked more to another field than to their respective own: both Economy (44.79\%) and Civil Society $(50.97 \%)$ linked the most to Media. It's especially interesting to see that in both cases roughly around $50 \%$ of the links refer to actors from the media indicating its importance for these fields. Another remarkable connection is between the fields of Civil Society and SIG. Whereas actors from the civil society linked in $21 \%$ of the cases to actors from SIG, this connection does not seem to be reciprocal: only $5.32 \%$ of the outgoing links from the field of SIG were directed towards actors from the civil society. Overall these findings suggest a little integrated online public sphere that is shaped by the social fields' self-referential linking practices.

By looking at the political field's outgoing links we were able to show that the most important fields for political actors are Public Administration, Civil Society and SIG. By looking at all the fields' connectedness it became obvious that most actors tend to link within their own field and that the field of Media seems to be very important within the network (as was already shown in Section 4.1).

\section{Discussion}

Taking on the one hand into account that a major energy transformation process in one of the world's leading economic and industrial powerhouses is a complex and very difficult task, which can only be worked on a systemic and intersocial level, the results of this study are a robust starting point for an analysis of the vital constellations of problems of the Energiewende. The description of the Energiewende case determined the need to integrate a broad range of different stakeholders and interactions of them and therefore serves as a good example for this special issue by establishing some shifts of political agency in the digital age. Indeed, the case of the Energiewende amplifies that tight descriptions of political processes do not fit any more for intersectoral issues which impact society as a whole. And the linking patterns suggest different degrees of political agency. Whereas political actors seem preoccupied with inter-party community building, actors from the civil society and special interest group reach out to other actors, bridge social fields and try to make their voices heard.

For the interpretation of our findings we must con- sider that the various types of media on the Internet may vary in terms of hyperlink practices. While hyperlinking is important for political bloggers to ensure visibility and to position themselves within the community, German mass media usually limit their outgoing links to sources and related articles on their own site. This does not necessarily weaken our findings, but it has to be kept in mind when interpreting the data.

Based on the public sphere theory we assumed that political actors are located in the centre of the debate and would try to integrate other actors within the discourse. Given the centrality of political decision-making in that case on the one hand and modern governance processes on the other hand it is plain to assume that politics shall play an important role in the integration of different stakeholder from the economic world, science and innovation actors as well as NGOs, the media and citizens.

These attempts, however, are as far as our online analysis could show not echoed via hyperlinks by the political field. Politics is rather circling around itself than integrating stakeholders. Whereas we assumed in the beginning that the political field has to interact with the different stakeholders in order to give them the feeling that their interests are being taken into consideration and are of relevance to politics our results showed that Politics referred in over $79 \%$ of the cases to itself. And even though the interaction between political actors and stakeholders will certainly be on a different level in the real life, hyperlinks also do signify attribution of significance.

From a governance and political decision-perspective one could assume that first, good decisions need appropriate information of the concerned stakeholders (Converse, 1990). Second, political actors have the duty not only to collect information for themselves, but to spread decision-relevant information to the public to justify their own position (Parvez \& Ahmed, 2006). In this analysis we did not find that information brokering and justification position. Rather political parties give almost no visible interest in other actors. They almost exclusively linked within their own party networks with the main website as most important link target.

Interestingly, the lack of a connective position is not only obvious in the political but also in other fields: most actors tend to link within their own field. Especially problematic in this respect is the total silence with regards to scientific actors. It would be easy to assume that a political party would link to a scientific source about the Energiewende in order to back their demands or ideas up scientifically. However, none of the relevant parties in Germany decided to do so. Our analysis also showed Science's irrelevance for other fields-except for the Media. We thus hypothesize that even though scientific facts and expertise are virtually around the corner the mass media remain the main source for scientific information-even online. Inter- 
estingly, however, the Media's role is an important topic within our analysis: even though the networked public sphere concept suggests that actors from the mass media are less relevant since other actors are able to connect with each other and forge alliances we see that most social fields heavily link to the mass media. Especially most of the quality newspapers are both productive and relevant within the network.

In general, the Energiewende's online discourse seems to be more fragmented than integrative. This, of course, is especially obvious when it comes to political actors but also actors from Public Administration. While Sunstein (2001) assumes that fragmentation and several loosely connected publics could be considered a danger for democracy, the Media played in the Energiewende-network an integrative role. This field was responsible for many outlinks and thus for observing the different social fields and integrating them in the wider public sphere. This is also true for actors from the civil society and SIG thus suggesting that these, even though not fully exploiting its potential (e.g. Benkler et al., 2015), are adapting to the Internet and its possibilities whereas politics is not.

\section{Conclusion}

This study's main interest was to take a closer look at one of the most ambitious projects in Germany's recent history: the Energiewende. We were especially interested in the Internet's potential in integrating many different actors from multiple social fields into the discourse. We also were interested in the role of the political field and whether it would try to reach out to different stakeholders in order to tackle the issue of Energiewende.

Our analysis showed however, that it is safe to say that the online network does not reflect the complexity and the systemic level of the problem: most actors only interact with other closely associated actors from their own social field. This is especially true for the "lone warriors" from the political field who neither deem NGOs nor civic movements relevant and who ignore scientific institutions altogether and thus fail their duty to collect, interpret and reflect different interests in the online Energiewende debate. It is thus worth noting that within the Energiewende public sphere there seems to be little integration of different actors even though this seems to be mandatory for such a high profile project.

Moreover, the findings of this study also add to the already broadly existing research investigations on the integrative potential of the Internet for democratic processes. Although our case was quite special and we should be careful not to conflate hyperlink relationships with political discourses per se, we can conclude that our findings suggest that integration processes within the networked public sphere do happen, albeit rarely. Our findings also lead to the conclusion, that especially the online platforms of traditional quality newspapers do fulfil the highly relevant task as intermediaries between actors from different social fields.

However, due to our focus on the hyperlink structures we are only able to speculate about the discourse's specific content with regard to frames and positions. Future research could include automated content analysis to further contextualize the different communities or identify potential polarizations alongside a specific position. Additionally, our interpretation of hyperlinks is limited to their function as vectors of relevance. Future research should also include an indepth interpretation of the specific meaning of references in order to further understand the content strategies of the authors involved in the discourse.

Additional research into the role of actors from SIG and the civil society seems imperative to understand with which methods these may enforce further integration. Especially foundations and NGOs seem to understand the logic of the world of online communication really well and a closer look into their online networks would be interesting. Another important future aspect of research is the connection of hyperlink analysis and social media in order to fully assess the online discourse on a subject.

\section{Acknowledgements}

Parts of this research were conducted within the project "Towards an Analytics of Networked Publics, TANEP" at the University of Vienna and funded by GfK Verein, Nuremberg (Germany).

\section{Conflict of Interests}

The authors declare no conflict of interests.

\section{References}

Adamic, L. A., \& Glance, N. (2005). The political blogosphere and the 2004 U.S. election: Divided they blog. In Proceedings of the 3rd International Workshop on Link Discovery (pp. 36-43). New York: ACM.

Althaus, M. (2012). Schnelle Energiewende: Bedroht durch Wutbürger und Umweltverbände? Protest, Beteiligung und politisches Risikopotenzial für Großprojekte im Kraftwerk- und Netzausbau Wissenschaftliche Beiträge. Wildau: TH Wildau.

Benkler, Y. (2006). The wealth of networks: How social production transforms markets and freedom. New Haven and London: Yale University Press.

Benkler, Y., Roberts, H., Faris, R., Solow-Niederman, A., \& Etling, B. (2015). Social mobilization and the networked public sphere: Mapping the SOPA-PIPA debate. Political Communication, 32(4), 594-624. doi:10.1080/10584609.2014.986349 
Blondel, V. D., Guillaume, J.-L., Lambiotte, R., \& Lefebvre, E. (2008). Fast unfolding of communities in large networks. Journal of Statistical Mechanics: Theory and Experiment, 2008(10), P10008.

BMWi, \& BMU. (2012). Erster Monitoringbericht: Energie der Zukunft. Berlin: Bundesministerium für Wirtschaft und Technologie \& Bundesministerium für Umwelt, Naturschutz und Reaktorsicherheit.

Camillus, J. C. (2008). Strategy as a wicked problem. Harvard Business Review, 86, 98-101.

Chang, T.-K., Himelboim, I., \& Dong, D. (2009). Open global networks, closed international flows: World system and political economy of hyperlinks in cyberspace. International Communication Gazette, 71(3), 137-159.

Converse, P. E. (1990). Popular representation and the distribution of information. In J. A. Ferejohn \& J. H. Kuklinski (Eds.), Information and democratic processes (pp. 369-388). Urbana and Chicago: University of Illinois Press.

Deutsch, M., Krampe, L., Peter, F., \& Rosser, S. (2014). Comparing the cost of low-carbon technologies: What is the cheapest option. Berlin: Prognos AG.

Ferree, M. M., Gamson, W. A., Gerhards, J., \& Rucht, D. (2002). Four models of the public sphere in modern democracies. Theory and Society, 31, 289-324.

Gawel, E., Strunz, S., \& Lehmann, P. (2012). The German Energiewende under attack: Is there an irrational Sonderweg? In UFZ-Diskussionspapiere (Vol. 15). Leipzig: Helmholtz Centre for Environmental Research.

Giddens, A. (1984). The constitution of society: Introduction of the theory of structuration. Berkeley: University of California Press.

Gonzalez-Bailon, S. (2009). Opening the black box of link formation: Social factors underlying the structure of the web. Social Networks, 31(4), 271-280.

Graichen, P. (2014). 10 questions and answers on the 2014 Reform of the German Renewable Energy Act. Berlin: Agora Energiewende.

Graichen, P., \& Redl, C. (2014). The German Energiewende and its climate paradox. An analysis of power sector trends for renewables, coal, gas, nuclear power and $\mathrm{CO} 2$ emissions 2010-2030. Berlin: Agora Energiewende.

Gruning, J., \& Hunt, T. (1984) Managing public relations. New York: Holt, Rinehart and Winston.

Habermas, J. (2006). Political communication in media society: Does democracy still enjoy an epistemic dimension? The impact of normative theory on empirical research. Communication Theory, 16(4), 411-426.

Harrison, C. (2002). Hypertext links: Whither thou goest, and why. First Monday, 7(10).

Hsu, C., \& Park, H. (2012). Sociology of hyperlink networks of web 1.0, web 2.0, and twitter: A case study of South Korea. In J. Hughes (Ed.), SAGE internet research methods (pp. IV237-IV255). London: Sage.

Kemfert, C. (2013). Kampf um Strom. Mythen, Macht und Monopole. Hamburg: Murmann.

Kemfert, C., \& Horne, J. (2013). Good governance of the Energiewende in Germany: Wishful thinking or manageable? In Hertie school experts on the German Federal Election 2013. Berlin: Hertie School of Governance.

Kleinen-von Königslöw, K. (2010). Die Arenen-Integration nationaler Öffentlichkeiten. Wiesbaden: VS Verlag für Sozialwissenschaften.

Latzer, M., \& Saurwein, F. (2006). Europäisierung durch Medien: Ansätze und Erkenntnisse der Öffentlichkeitsforschung. In W. Langenbucher \& M. Latzer (Eds.), Europäische Öffentlichkeit und medialer Wandel. Eine transdisziplinäre Perspektive (pp. 10-45). Wiesbaden: VS Verlag.

Mueller, D., Ligensa, A., \& Gendolla, P. (2009). Leitmedien. Konzepte-Relevanz-Geschichte. Bielefeld: Transcript Verlag.

Nahon, K., \& Hemsley, J. (2013). Going viral. Cambridge: Polity Press.

Neuberger, C. (2009). Internet, Journalismus und Öffentlichkeit: Analyse des Medienumbruchs. In C. Neuberger, C. Nuernbergk \& M. Rischke (Eds.), Journalismus im Internet (pp. 19-105). Wiesbaden: VS Verlag für Sozialwissenschaften.

Park, H. W. (2003). Hyperlink network analysis: A new method for the study of social structure on the web. Connections, 25(1), 49-61.

Parvez, Z., \& Ahmed, P. (2006) Towards building an integrated perspective on e-democracy. Information, Communication \& Society, 9(5), 612-632.

Rhomberg, M., \& Stehr, N. (2012). Environmental change. In G. Ritzer (Ed.), The Wiley-Blackwell encyclopedia of globalization. Boston: Blackwell Publishing.

Rittel, H. W., \& Webber, M. M. (1973). Dilemmas in a general theory of planning. Policy Sciences, 4, 155-169.

Schumate, M. (2012). The evolution of the HIV/AIDS NGO hyperlink network. Journal of ComputerMediated Communication, 17, 120-134.

Sohre, A. (2012). Strategien in der Energie- und Klimapolitik. Bedingungen strategischer Steuerung der Energiewende in Deutschland und Großbritannien. Wiesbaden: Springer VS.

Stieglitz, S., \& Dang-Xuan, L. (2012). Social media and political communication: A social media analytics framework. Social Network Analysis and Mining, 3(4), 1277-1291.

Sunstein, C. (2001). Republic.com. Princeton, NJ: Princeton University Press.

The Economist. (2012). Energiewende. Retrieved from http://www.economist.com/node/21559667

Wessler, H. (2002). Multiple Differenzierung und kommunikative Integration: Symbolische Gemeinschaften und Medien. In K. Imhof, O. Jarren, \& R. Blum (Eds.), Integration und Medien (Vol. 7, pp. 56-76). Wiesbaden: VS Verlag für Sozialwissenschaften. 


\section{About the Authors}

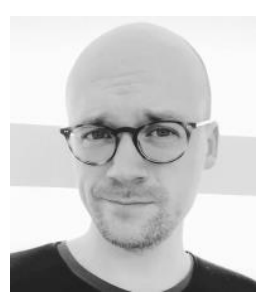

Jonas Kaiser is Jonas Kaiser is a PhD candidate at Zeppelin University Friedrichshafen, an Associate Researcher at Alexander von Humboldt Institute for Internet \& Society, and a Fellow at Berkman Klein Center for Internet \& Society at Harvard University. His research focus is on political and environmental communication in the networked public sphere.

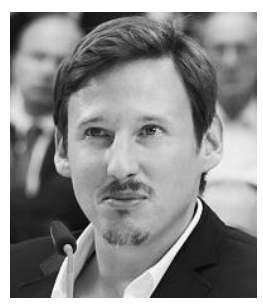

Markus Rhomberg is Professor and Chair of Political Communication at Zeppelin University Friedrichshafen (Germany), Faculty of Political and Social Sciences. He was fellow for Political Communication at the Mercator Foundation in Berlin and Acting Professor for Empirical Communication Research at the University of Hamburg. His research interests include political and science communication.

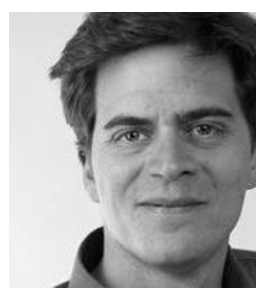

Axel Maireder, Dr., is Head of Social Media Research at the global market research company GfK. Prior to joining GfK in 2015, Axel worked at the University of Vienna's Department of Communication, focusing on the study of practices and dynamics of social media communication with a focus on political communication.

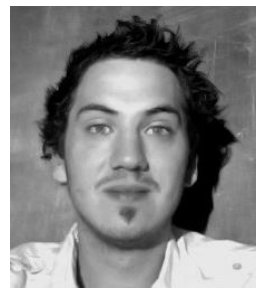

Stephan Schlögl is researcher at GfK Austria and PhD candidate at the Institute of Development Studies at the University of Vienna. He studies digital inequalities in transnational public spheres focusing on the unequal distribution of attention between the Global North and South in social media. 